\title{
PEMANFAATAN KOMPOS TANDAN KOSONG KELAPA SAWIT UNTUK MENINGKATAN PERTUMBUHAN TANAMAN KAYU PUTIH (Melaleuca cajuputi) DI LAHAN PASCA TAMBANG BATUBARA
}

\author{
Utilization of Empty Fruit Bunch Compost on Improving Melaleuca cajuputi at Coal Post- \\ Mining
}

Agus Ari Subagio $^{1 *}$, Irdika Mansur ${ }^{2}$, dan Rita Kartika Sari ${ }^{3}$

(Diterima Desember 2017 / Disetujui Februari 2018)

\begin{abstract}
Compost of oil palm empty bunches can improve fertility and soil nutrient on ex-mining land. This study aimed to evaluate the effect of oil palm empty fruit bunches composted on growth of Melaleuca cajuputi on post-mining land. This research was conducted at field for 3 months. The application was done at 1 to 3 years plant age. A single factor of empty fruit bunch compost organized on RCBD with 4 treatments and 4 replication. The results showed the compost able to increase growth of $\mathrm{M}$. cajuputi. The best application was $K 1\left(5 \mathrm{~kg} \mathrm{plant}^{-1}\right)$ increased height of 1 and 2 years plant age respectively by 67.82 and $38.86 \%$. K2 (7.5 $\left.\mathrm{kg}^{\text {plant }}{ }^{-1}\right)$ at 3 years old increased by $30.16 \%$. While the highest yield of diameter increased was on $\mathrm{K} 2\left(7.5 \mathrm{~kg} \mathrm{plant}^{-1}\right)$ at 1 and 3 years plant age $(46.05 \%$ and $30.85 \%)$. The 2 year plant age with dose $\mathrm{K} 3\left(10 \mathrm{~kg} \mathrm{plant}^{-1}\right)$ was increased of $32.09 \%$. In general, the application of EFB compost such as K1 treatment $\left(5 \mathrm{~kg}\right.$ plants $\left.^{-1}\right)$ was reached the best dose of 1 and 2 year plant age and $\mathrm{K} 2$ treatment $\left(7.5 \mathrm{~kg}\right.$ plant $\mathrm{t}^{-1}$ ) gave the best response for 3 years of plant age.
\end{abstract}

Key words: empty fruit bunch, EFB, Melaleuca cajuputi, postcoal-mining land

\section{PENDAHULUAN}

Selain menghasilkan manfaat kegiatan pertambangan juga menimbulkan permasalahan, terutama terhadap lingkungan. Penambangan batubara menyebabkan kandungan bahan organik dan kesuburan tanahnya menurun, serta ketersediaan hara tanaman rendah (Talaohu \& Irawan 2008). Lahan pasca pertambangan batubara yang umumnya gersang, vegetasi sulit tumbuh dan lahan menjadi tidak produktif memerlukan penanganan yang serius. Pemilihan jenis pohon kehutanan yang akan ditanam untuk revegetasi lahan bekas tambang sangat penting untuk menghadapi lahan yang marjinal dan untuk meningkatkan kualitas dari hasil reklamasi lahan dilihat dari aspek ekologi, ekonomi dan sosial (Mansur 2008).

Pemberdayaan lahan-lahan bekas tambang juga telah dilakukan oleh perusahaan-perusahaan pertambangan yang memiliki komitmen tinggi pada pengembangan masyarakat dan lingkungan. PT. Bukit Asam (PT. BA) misalnya, memilih jenis pohon kayu putih (Melaleuca

1 Mahasiswa Pascasarjana PS Silvikultur Tropika, Fakultas Pascasarjana, IPB

* Penulis korespondensi:

e-mail : aria7997@gmail.com

2 Staf Pengajar Dept. Silvikultur, Fakultas Kehutanan IPB

3 Staf Pengajar Dept. Teknologi Hasil Hutan, Fakultas

Kehutanan IPB cajuputi) sebagai salah satu jenis pohon untuk merevegetasi sebagian lahan bekas tambangnya. Daundaun dari kayu putih dipanen dan diekstrak menjadi minyak kayu putih sehingga menghasilkan produk dengan nilai ekonomi tinggi tanpa harus menebang pohon-pohon yang harus ditanam (Mansur 2013). Indonesia kaya akan jenis pohon yang mampu beradaptasi dengan berbagai kondisi lahan. Potensi kayu putih cukup besar tersebar di hutam alam (Maluku, Sulawesi Tenggara, Bali, NTT, dan Papua) dan hutan tanaman (Jawa Timur, Jawa Tengah, DI Yogyakarta, dan Jawa Barat) (Gunn et al. 1996; Perum Perhutani 2005; Utomo 2012). Jenis kayu ini dapat beradaptasi dengan tanah yang sangat masam, tergenang sampai tanah kering (Mansur 2013). Pemanfaatan minyak kayu putih secara komersial di Indonesia telah lama dilakukan, yakni sejak tahun 1924 khususnya dalam skala industri besar yang berawal dari kegiatan rehabilitasi lahan marjinal (Budiadi et al. 2005).

Pengelolaan tegakan merupakan kunci keberhasilan dari pengelolaan hutan secara keseluruhan. Penanganan tegakan dimulai dari persiapan lapangan, persiapan bibit, penanaman, pemeliharaan (Utomo 2012). Pemupukan merupakan salah satu upaya untuk meningkatkan pertumbuhan kayu putih. Pemupukan merupakan upaya penambahan bahan-bahan lain yang dapat memperbaiki sifat-sifat tanah misalnya pemberian pasir dalam tanah liat, penambahan bahan mineral pada tanah organik, pengapuran dan sebagainya 
(Hardjowigeno 2007). Limbah yang dihasilkan oleh perkebunan kelapa sawit dapat berupa limbah padat seperti tandan kosong, pelepah sawit dan daun sawit (Bulan 2016). Menurut Darnoko \& Ady (2006), kompos TKKS memiliki keunggulan antara lain kandungan kalium tinggi, tanpa penambahan starter dan bahan kimia, memperkaya unsur hara yang ada didalam tanah, dan mampu memperbaiki sifat fisik, kimia dan biologi. Selan itu, berdasarkan penelitian yang dilakukan (Winarti \& Neneng 2013) menunjukkan perlakuan pemberian TKKS pada tanah pasir bekas tambang emas menunjukkan kenaikan $\mathrm{pH}$ menjadi 6.35. Penelitian ini bertujuan mengevaluasi pengaruh pemberian kompos tandan kosong kelapa sawit terhadap pertumbuhan tanaman kayu putih di lahan pasca tambang.

\section{METODE PENELITIAN}

\section{Tempat dan Waktu Penelitian}

Penelitian ini dilaksanakan di PT. Bukit Asam Tbk. Sumatera Selatan dari bulan Februari sampai Mei 2017. Analisis tanah dilakukan di laboratorium Batubara dan laboratorium Eksplorasi milik PT. BA dan di Laboratorium Fisika dan Kimia Tanah, Departemen Ilmu Tanah dan Sumber Daya Lahan IPB.

\section{Bahan dan Alat}

Bahan-bahan yang digunakan antara lain tanaman kayu putih berumur 1 sampai dengan 3 tahun setelah tanam, kompos TKKS. Alat-alat yang digunakan yaitu cangkul, sekop, patok, ajir, label plot percobaan, alat tulis, kamera, meteran, penggaris, timbangan, gunting, tally sheet, kamera, Pengelolaan dan analisis data menggunakan seperangkat komputer yang dilengkapi perangkat lunak Microsoft Office 2010 dan mengunakan program SAS 9.0.

\section{Prosedur Penelitian}

\section{Analisis tanah}

Pengambilan contoh tanah di lapangan dilakukan dengan teknik komposit dan ring sampel, untuk sampel tanah yang diambil pada level kedalaman $0-20 \mathrm{~cm}$. Sampel tanah diambil pada empat titik arah mata angin dan di tengah-tengah plot. Contoh tanah yang diperoleh dari 5 titik dengan berat yang sama, kemudian dicampurkan secara merata untuk memperoleh 1 campuran tanah komposit, yang selanjutnya digunakan untuk keperluan analisis di laboraturium. Sampel tanah dimasukkan ke dalam kantong plastik untuk kemudian diuji sifat fisik yaitu tekstur 3 fraksi dan sifat kimia antara lain pH, C-Organik, KTK, rasio C/N, P-Total, KTotal (Balit tanah 2009).

\section{Pemberian perlakuan}

Pemupukan dilakukan sesuai perlakuan dengan mengikuti perlakuan kompos yang telah ditentukan. Aplikasi kompos dilakukan dengan membuat alur yang mengelilingi tanaman dengan kedalaman sekitar 10 sampai $20 \mathrm{~cm}$ dan radius 40 sampai $50 \mathrm{~cm}$ dari batang tanaman kemudian kompos segera dimasukkan dalam alur tersebut dan setelah itu alur ditutup kembali pada bekas galian sebelumnya.

\section{Pemeliharaan tanaman}

Pemeliharaan tanaman yang akan dilakukan meliputi kegiatan penyiangan, penyiraman, dan pemberantasan hama penyakit yang dilakukan sesuai kondisi tanaman di lapangan.

\section{Evaluasi pengaruh pemberian kompos tandan kosong kelapa sawit}

Parameter pertumbuhan yang diamati meliputi: pertumbuhan tinggi, diameter, serta panjang dan lebar tajuk.

\section{Pengukuran tinggi}

Pada Pengukuran pertumbuhan tinggi tanaman kayu putih umur tanaman 1 sampai dengan 3 tahun dilakukan menggunakan meteran, tanaman kayu putih diukur mulai dari pangkal batang sampai titik tumbuh kayu putih. Pada pangkal batang yang diberi tanda sebagai awal pengukuran. Pengukuran dilakukan 2 minggu sekali elama 3 bulan.

\section{Pengukuran diameter}

Pertumbuhan diameter tanaman kayu putih dalam penelitian ini adalah pertambahan lingkar tanaman kayu putih dimana pengukuran pada batang yang telah ditandai sebelumnya dilakukan setiap 2 minggu sekali.

\section{Pengukuran tajuk}

Pengukuran dilakukan terhadap lebar tajuk tanaman kayu putih berumur 1 sampai dengan 3 tahun dengan menggunakan meteran dan pita ukur pada proyeksi tajuk yang akan diamati sedangkan untuk pengukuran tajuk dilakukan setiap 2 minggu.

\section{Analisis Data}

\section{Rancangan percobaan dan analisis data}

Percobaan disusun dengan menggunakan rancangan acak kelompok (RAK) dengan faktor tunggal yaitu dosis Kompos. Perlakuan disusun sebagai berikut:

Dosis kompos:

K0 : Tanpa pemberian Kompos

$\mathrm{K} 1$ : Kompos $5 \mathrm{~kg} \operatorname{tanaman}^{-1}$

$\mathrm{K} 2$ : Kompos $7.5 \mathrm{~kg} \operatorname{tanaman}^{-1}$

$\mathrm{K} 3$ : Kompos $10 \mathrm{~kg} \operatorname{tanaman}^{-1}$

Terdapat 4 perlakuan yang diulang sebanyak 4 kali sehingga total terdapat 16 satuan percobaan. Setiap satuan percobaan terdapat 3 umur tanaman yaitu 1, 2 dan 3 tahun sehingga total dibutuhkan 48 tanaman. 
Model linier Rancangan acak kelompok adalah sebagai berikut

$$
\mathrm{Yijk}=\mu+\tau_{\mathrm{i}}+\mathrm{B}_{\mathrm{j}}+\sum \mathrm{ijk}
$$

Ket:

Yijk = Nilai pengamatan respon pada pengaruh perlakuan dosis kompos taraf ke-i dan kelompok umur ke-j

$\mu \quad=$ Rataan umum

$\tau_{\mathrm{i}}=$ Pengaruh perlakuan dosis kompos taraf ke-i

$\mathrm{B}_{\mathrm{j}} \quad=$ Pengaruh kelompok ke-j

$\sum \mathrm{ijk}=$ Pengaruh acak pada perlakuan ke-i dan kelompok ke-j

Data hasil pengukuran dianalisis dengan sidik ragam pada taraf nyata 5\% untuk mengetahui perbedaan antar perlakuan menggunakan software SAS 9.0. Jika terdapat perbedaan nyata $(\mathrm{P}<0.05)$ maka akan diuji lanjut dengan uji jarak berganda Duncan (DMRT) untuk mengetahui perlakuan terbaik.

\section{HASIL DAN PEMBAHASAN}

\section{Hasil Analis Tanah di PT. Bukit Asam Tbk.} Sumatera Selatan

Pertumbuhan tanaman sangat dipengaruhi oleh ketersediaan unsur hara dalam tanah. Sehingga perlu dilakukan analilis untuk mengetahui ketersedian nutrisi hara yang terdapat di dalamnya. Hasil analisis beberapa sifat kimia tanah di lokasi penelitian disajikan pada Tabel 1. Tabel 1 menunjukkan bahwa kondisi lahan yang digunakan untuk penelitian ini termasuk dalam kategori masam dan miskin unsur hara. Berdasarkan hasil evaluasi kesuburan tanah pada berbagai umur tanaman menunjukkan rata-rata $\mathrm{pH}$ tanah pada umur 1 tahun bersifat masam, sedangkan pada umur 2 dan 3 tahun pH tanah tergolong sangat masam (Balai Penelitian Tanah 2009). Berdasarkan kriteria Balai Penelitian Tanah (2009) hasil analisis C organik tanah pada umur 1 sampai dengan 3 tahun masuk dalam kategori rendah. Nilai KTK tanah pada umur 2 tahun berkategori sangat rendah, sedangkan pada umur 1 dan 3 tahun termasuk kategori sedang yaitu (nilainya 17-24 $\mathrm{cmol} / \mathrm{kg}$ ). Selain itu tekstur 3 fraksi umur 1 dan 3 tahun tipe tanah tergolong clay loam sedangkan untuk pada 2 tahun tanah masuk dalam tipe clay (USDA 1987). Nilai

rasio $\mathrm{C} / \mathrm{N}$ sangat tinggi pada umur 3 tahun kemudian rasio $\mathrm{C} / \mathrm{N}$ yang sedang ini menyebabkan unsur hara di dalam tanah cukup banyak tersedia bagi tanaman. Berdasarkan kriteria penilaian sifat kimia tanah yang dibuat oleh Balai Penelitian Tanah (2009), unsur hara P pada umur 1 dan 3 tahun dikategorikan sedang, kemudian pada umur 2 tahun masuk dalam ketegori sangat rendah. Kekurangan unsur hara $\mathrm{P}$ pada tanah disebabkan oleh kandungan $\mathrm{P}$ dari bahan induk tanah yang rendah, maupun kandungan $\mathrm{P}$ sebetulnya tinggi tetapi tidak tersedia untuk tanaman karena diserap oleh unsur lain seperti Al dan Fe (Prasetyo \& Suriadikarta, 2006). Sedangkan unsur hara $\mathrm{K}$ pada umur 1 dan 2 tahun dikategorikan tinggi dan pada umur 3 tahun masuk dalam kategori sangat tinggi.

Respon pengaruh aplikasi kompos yang berasal dari tandan kosong kelapa sawit (TKKS) terhadap peningkatan persediaan nutrisi hara di dalam tanah serta memperbaiki sifat fisik maupun kimia yang bertujuan untuk mendukung pertumbuhan tanaman. Oleh karena itu dilakukan analisis tanah lanjutan untuk mengetahuinya (Tabel 2).

Pada Tabel 2 dapat dilihat bahwa setelah perlakuan kompos menunjukkan adanya peningkatan nilai $\mathrm{pH}$ pada umur 2 dan 3 tahun dikategorikan masam kemudian pada umur 1 tahun $\mathrm{pH}$ tanah yang awalnya tergolong masam menjadi netral (Balai Penelitian Tanah 2009). Hasil analisis C organik pada umur 1 sampai 3 tahun mengalami peningkatan sehingga termasuk kategori sedang. Selain itu nilai KTK tanah pada umur 1 dan 2 tahun termasuk kategori sedang, dan pada umur 3 tahun berkategori tinggi. Menurut Stevenson (1982) pengaruh bahan organik sebagai sumber hara di dalam tanah dan sebagai faktor meningkatkan KTK tanah.

Tabel 2 Hasil analisis tanah PT BA sesudah aplikasi kompos tandan kosong kelapa sawit (TKKS) tiap umur tanaman

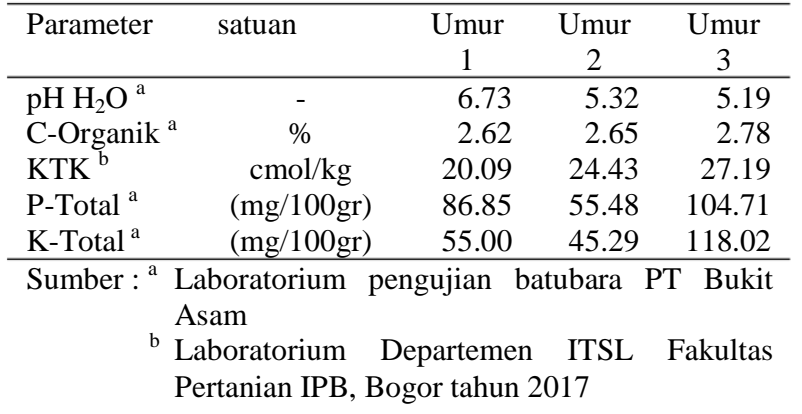

Tabel 1 Hasil analisis tanah pasca tambang PT. BA tiap umur tanaman sebelum aplikasi kompos tandan kosong kelapa sawit (TKKS)

\begin{tabular}{|c|c|c|c|c|c|c|}
\hline Parameter & & satuan & Umur 1 & Umur 2 & Umur 3 & Standar media tanam \\
\hline $\mathrm{pH} \mathrm{H}_{2} \mathrm{O}^{\mathrm{a}}$ & & - & 4.95 & 4.05 & 3.78 & $6.6-7.5$ \\
\hline C-Organik ${ }^{\mathrm{a}}$ & & $\%$ & 0.87 & 1.18 & 1.88 & $>5$ \\
\hline $\mathrm{KTK}^{\mathrm{b}}$ & & $\mathrm{cmol} / \mathrm{kg}$ & 21.28 & 16.15 & 21.28 & $>40$ \\
\hline \multirow[t]{3}{*}{ Tekstur 3 Fraksi } & Pasir $^{a}$ & $\%$ & 24.50 & 34.20 & 30.40 & $22.5-52.5$ \\
\hline & Debu $^{a}$ & $\%$ & 41.10 & 23.90 & 34.90 & $30-50$ \\
\hline & Liat $^{a}$ & $\%$ & 34.40 & 41.90 & 34.70 & $10-30$ \\
\hline Rasio $C / N^{a}$ & & - & 12.41 & 13.53 & 40.83 & $>25$ \\
\hline P-Total ${ }^{\mathrm{a}}$ & & $(\mathrm{mg} / 100 \mathrm{gr})$ & 23.68 & 5.73 & 27.34 & $>60$ \\
\hline K-Total ${ }^{\text {a }}$ & & $(\mathrm{mg} / 100 \mathrm{gr})$ & 46.76 & 44.09 & 69.48 & $>60$ \\
\hline
\end{tabular}

Sumber: ${ }^{\text {a}}$ Laboratorium pengujian batubara PT. Bukit Asam

${ }^{\mathrm{b}}$ Laboratorium Departemen ITSL Fakultas Pertanian IPB, Bogor tahun 2017 
Pada tanaman yang diberikan kompos terlihat kandungan unsur hara $\mathrm{P}$ pada semua umur tanaman mengalami peningkatan yaitu nilai antara 5-27 dari menjadi 55-104. Unsur hara $\mathrm{P}$ membantu dalam membentuk protein dan mineral yang dibutuhkan bagi tanaman, bertugas mengedarkan energi ke seluruh bagian tanaman, merangsang pertumbuhan dan perkembangan akar (Kurniaty et al. 2013). Berdasarkan kriteria penilaian sifat kimia tanah yang dibuat oleh Balai Penelitian Tanah (2009) dimana unsur hara K tanah pada semua umur tergolong dalam kriteria sangat tinggi. Menurut Siregar et al. (2013) peningkatan kandungan bahan organik tanah memberikan pengaruh pada kualitas tanah dan paremeter-parameter lainnya antara lain KTK, pH, serta beberapa unsur hara tanah seperti N, P, K, dan Ca. Menurut Sarwono (2008) menyebutkan bahwa penggunaan pupuk organik dapat digunakan sebagai subtitusi pupuk anorganik dalam usaha konservasi lahan.

\section{Respon Pertumbuhan Kayu Putih}

Aplikasi kompos TKKS menunjukkan pengaruh nyata terhadap pertumbuhan kayu putih pada parameter tinggi, diameter, dan lebar tajuk (Tabel 3). Hasil analisis sidik ragam menjelaskan perlakuan tersebut sangat berbeda nyata pada tinggi, diameter, dan lebar tajuk semua umur. Pada umur muda dimana tanaman lebih melakukan pertumbuhan cepat ke arah vertikal (ke atas), selanjutnya pertumbuhan diameter apabila keperluan hasil fotosintesis untuk respirasi, pergantian daun, pergantian akar, dan tinggi telah terpenuhi (Lewenussa 2009). Selanjutnya berdasarkan hasil tersebut dilakukan uji lanjut Duncan pada masing-masing peubah.

Hasil rekapitulasi menunjukan perlakuan kompos berpengaruh hampir pada setiap minggu pengamatan terhadap pertambahan tinggi tanaman (Gambar 1). Pemberian kompos tidak berpengaruh terhadap awal pertambahan tinggi tanaman pada 2 MSP umur 1 tahun. Pada 2 MSP pupuk kompos diduga belum dibutuhkan untuk awal pertumbuhan. Pada umur 2 dan 3 tahun perlakuan pupuk kompos berpengaruh pada setiap pengamatan (Tabel 3). Sedangkan pada diameter berpengaruh nyata umur 1 dan 2 tahun pada setiap pengamatan selain itu respon di tunjukan umur 3 tahun

Tabel 3 Rekapitulasi hasil analisis sidik ragam pengaruh kompos terhadap peubah pertumbuh yang diamati

\begin{tabular}{lc}
\hline Peubah & Kompos TKKS \\
\hline Pertambahan tinggi $(\mathrm{cm})$ & $*$ \\
Umur 1 Tahun & $* *$ \\
Umur 2 Tahun & $* *$ \\
Umur 3 Tahun & \\
Pertambahan diameter $(\mathrm{cm})$ & $* *$ \\
Umur 1 Tahun & $* *$ \\
Umur 2 Tahun & $*$ \\
Umur 3 Tahun & \\
Pertambahan lebar tajuk $(\mathrm{cm})$ & tn \\
Umur 1 Tahun & tn \\
Umur 2 Tahun & $* *$ \\
Umur 3 Tahun &
\end{tabular}

Ket : tn $=$ berpengaruh tidak nyata pada $(\mathrm{P}>0.05)$

* = berpengaruh nyata pada $(0.01<\mathrm{P} \leq 0.05)$

$* *$ = berpengaruh nyata pada $(\mathrm{P} \leq 0.01)$ pada 8 MSP. Pemberian kompos tidak berpengaruh nyata terhadap peubah pertambahan lebar tajuk pada kelas umur 1 dan 2 tahun setiap pengamatan namun respon cukup baik ditunjukkan pada kelas umur 3 tahun dimana menunjukkan perlakuan kompos berpengaruh nyata pada 6 dan $8 \mathrm{MSP}$.

\section{Tinggi dan Diameter Kayu Putih}

Berdasarkan hasil uji Duncan Tabel 4 memperlihatkan bahwa nilai tertinggi pertambahan tinggi pada umur 1 tahun dan 2 tahun ditunjukkan pada K1 (5 kg tanaman $\left.{ }^{-1}\right)$ kemudian pada umur 3 tahun perlakuan K2 $\left(7.5 \mathrm{~kg} \operatorname{tanaman}^{-1}\right)$. Hal ini menunjukkan sebagai taraf kompos K1 terbaik dibandingkan dengan taraf lainnya. Persentase peningkatan tinggi perlakuan $\mathrm{K} 1\left(5 \mathrm{~kg}\right.$ tanaman $\left.^{-1}\right)$ terhadap kontrol (K0) umur 1 dan 2 tahun secara berturut - turut sebesar $67.82 \%$ dan $38.86 \%$, sedangkan perlakuan $\mathrm{K} 2\left(7.5 \mathrm{~kg}\right.$ tanaman $\left.^{-1}\right)$ umur 3 tahun sebesar $30.16 \%$ Selain itu, K2 $(7.5 \mathrm{~kg}$ $\operatorname{tanaman}^{-1}$ ) juga menunjukkan pengaruh terbaik pada peubah diameter umur 1 dan 3 tahun yaitu $46.05 \%$ dan $30.85 \%$. Pada umur 2 tahun peubah diameter sebesar $32.09 \%$ pada perlakuan K3 $\left(10 \mathrm{~kg}\right.$ tanaman $\left.^{-1}\right)$.

Pertambahan tinggi tanaman sendiri merupakan salah satu ukuran yang paling sering diamati karena merupakan salah satu indikator pertumbuhan maupun indikator untuk mengetaui sejauh mana pengaruh lingkungan ataupun pengaruh perlakuan yang digunakan (Sitompul \& Guritno 1995). Selain itu perlakuan kompos memberikan pengaruh terhadap pertumbahan tinggi tanaman dimana memiliki keterkaitan dengan pertambahan diameter tanaman. Hal ini sesuai dengan Darmawan \& Baharsjah (2010) pertumbuhan merupakan pertambahan volume dan massa dari suatu tanaman, dimana ditandai dengan pertumbuhan primer maupun sekunder, yaitu pertumbuhan sekunder terjadi pada jaringan kambium dimana berkorelasi dengan pertambahan diameter tanaman tersebut.

Tabel 4 Pengaruh kompos terhadap respon pertambahan tinggi dan diameter kayu putih pengamatan 8 minggu setelah perlakuan (MSP)

\begin{tabular}{clll}
\hline \multirow{2}{*}{ Lokasi } & \multirow{2}{*}{ Perlakuan } & \multicolumn{2}{c}{ Parameter } \\
\cline { 3 - 4 } & & & \multicolumn{1}{c}{ Tinggi } \\
Umur 1 tahun & & $15.5 \mathrm{~b}$ & $0.21 \mathrm{~b}$ \\
& $\mathrm{~K} 0$ & $27.25 \mathrm{a}$ & $0.41 \mathrm{a}$ \\
& $\mathrm{K} 1$ & $20.25 \mathrm{ab}$ & $0.46 \mathrm{a}$ \\
& $\mathrm{K} 2$ & $26.75 \mathrm{a}$ & $0.45 \mathrm{a}$ \\
Umur 2 tahun & $\mathrm{K} 3$ & $14.25 \mathrm{~b}$ & $0.55 \mathrm{~b}$ \\
& $\mathrm{~K} 0$ & $36.75 \mathrm{a}$ & $0.85 \mathrm{ab}$ \\
& $\mathrm{K} 1$ & $34.00 \mathrm{a}$ & $0.80 \mathrm{ab}$ \\
& $\mathrm{K} 2$ & $28.50 \mathrm{a}$ & $0.90 \mathrm{a}$ \\
& $\mathrm{K} 3$ & & \\
& & $19.00 \mathrm{c}$ & $0.47 \mathrm{~b}$ \\
& $\mathrm{~K} 0$ & $24.25 \mathrm{~b}$ & $0.63 \mathrm{ab}$ \\
& $\mathrm{K} 1$ & $30.25 \mathrm{a}$ & $0.74 \mathrm{a}$ \\
& $\mathrm{K} 2$ & $29.00 \mathrm{a}$ & $0.73 \mathrm{a}$ \\
\hline
\end{tabular}

Ket: angka-angka yang diikuti oleh huruf yang sama pada kolom yang sama menunjukkan tidak berbeda nyata pada taraf $\alpha 5 \%$. K0: kontrol; $\mathrm{K} 1$ : dosis $5 \mathrm{~kg} /$ tanaman; $\mathrm{K} 2$ : dosis $7.5 \mathrm{~kg} /$ tanaman; $\mathrm{K} 3$ : dosis $10 \mathrm{~kg} /$ tanaman. 


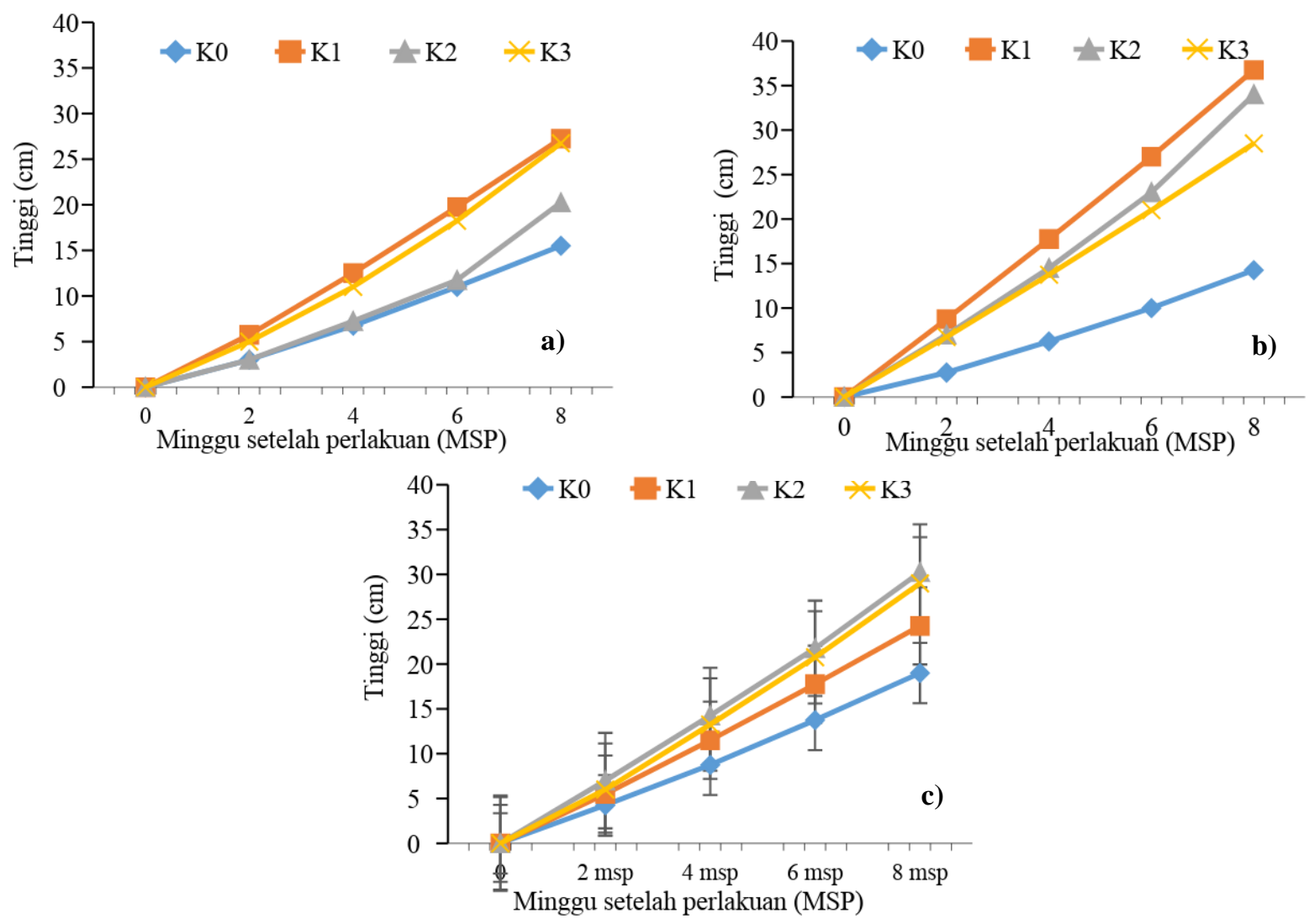

Gambar 1 Pengaruh aplikasi Kompos (K) terhadap pertambahan tinggi beberapa minggu setelah perlakuan (MSP).K0: kontrol; K1: dosis $5 \mathrm{~kg}$; K2: dosis $7.5 \mathrm{~kg}$; K3: dosis $10 \mathrm{~kg}$. (a) Umur 1 tahun , (b) Umur 2 tahun dan (c) Umur 3 tahun
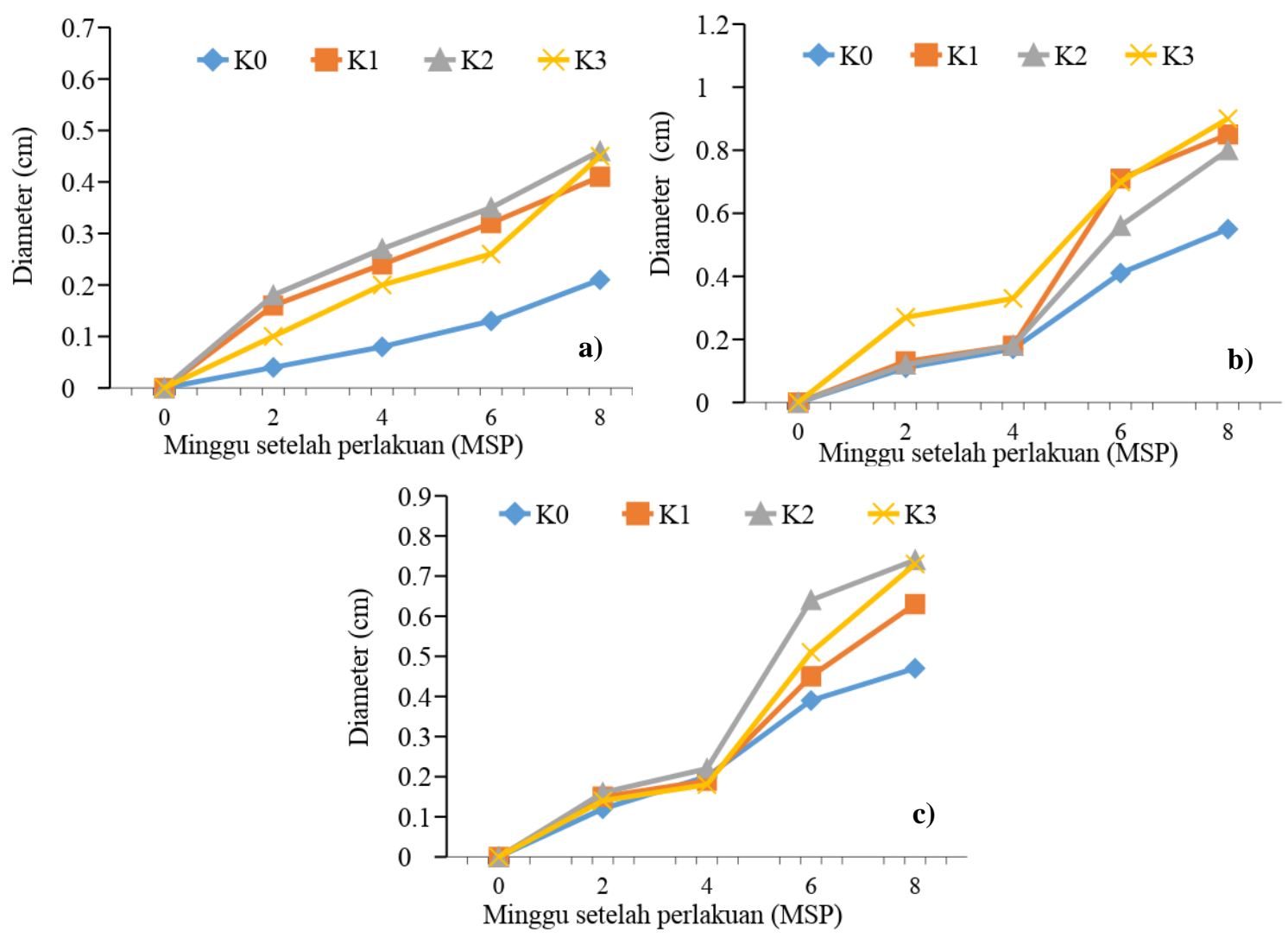

Gambar 2 Pengaruh aplikasi Kompos (K) terhadap pertambahan diameter kayu putih (Melaleuca Cajuputi) beberapa minggu setelah perlakuan (MSP. K0: kontrol; K1: dosis $5 \mathrm{~kg}$; K2: dosis 7.5kg; K3: dosis 10kg. (a) Umur 1 tahun, (b) Umur 2 tahun, dan (c) Umur 3 tahun 


\section{Aplikasi Kompos Terhadap Pertumbuhan Tanaman Kayu Putih}

\section{Tinggi dan diameter tanaman}

Perlakuan Kompos TKKS yang diaplikasikan pada tanaman di areal reklamasi memberikan respon yang baik terhadap pertumbuhan tanaman kayu putih yang diamati yaitu baik pada tingkat pertumbuhan tinggi dan diameter batang tanaman kayu putih. Perlakuan aplikasi TKKS terhadap pertumbuhan tanaman ditunjukkan pada Gambar 1. Dimana setiap perlakuan yang diaplikasikan pada berbagai kelas umur tanaman memiliki respon yang berbeda-beda.

\section{Tinggi tanaman}

Respon tanaman pada aplikasi kompos (TKKS) terlihat memberikan pengaruh peningkatan pada tinggi dimana pada Gambar 1 ditunjukkan trend pertumbuhan tanaman tersebut dari waktu pengamatan 2 MSP sampai dengan $8 \mathrm{MSP}$ jika dibandingkan dengan K0 atau kontrol yang pertumbuhanan tingginya lebih lambat. Hal ini menunjukkan bahwa kandungan unsur hara yang terdapat pada setiap perlakuan kompos meningkatkan pertambahan tinggi karfna kebutuhan telah terpenuhi.

Perlakuan K1 $\quad\left(5 \quad \mathrm{~kg} \quad \operatorname{tanaman}^{-1}\right) \quad$ mampu meningkatkan pertumbuhan tinggi tanaman umur 1 tahun dari $5.75 \mathrm{~cm}$ menjadi $27.25 \mathrm{~cm}$ dan pada umur 2 tahun menunjukkan peningkatan secara nyata dari 8.75 $\mathrm{cm}$ menjadi $36.75 \mathrm{~cm}$. Selain itu pertambahan tinggi pada umur 3 tahun dimana respon terbaik ditunjukkan pada perlakuan $\mathrm{K} 2 \quad\left(7.5 \mathrm{~kg}\right.$ tanaman $\left.^{-1}\right)$ adanya peningkatan dari $7.00 \mathrm{~cm}$ menjadi $30.25 \mathrm{~cm}$. Hal ini dikarenakan adanya pertambahan unsur hara $\mathrm{K}$ di dalam tanah sehingga mampu meningkatkan pertumbuhanan tinggi tanaman. Pendapat tersebut didukung oleh Hakim et al. (1986) bahwa kalium (K) mempunyai peran yang tidak kalah penting dalam proses-proses fisiologis seperti mengatur aktivitas beragam unsur mineral, mengatur pergerakan stomata dan pertumbuhan jaringan meristematik.

\section{Diameter tanaman}

Pemberian pupuk kompos yang diamati selama (8 MSP) terlihat memberikan pengaruh yang signifikan terhadap pertumbuhan diameter tanaman kayu putih. Diameter batang tanaman dengan berbagai dosis perlakuan memberikan peningkatan pertumbuhan diameter terbesar terhadap kontrol (K0). Hal ini diduga karena semakin membaiknya faktor lingkungan sehingga mempengaruhi pertumbuhan tanaman. Pendapat tersebut didukung oleh Purwowidodo (1991) kondisi kesuburan tanah dapat berdampak terhadap perilaku fisiologis tanaman dan ditunjukkan oleh perkembangan riap tumbuh, seperti diameter dan tinggi.

Penggunaan unsur hara oleh tanaman terus terjadi hingga akhir pengamatan, terlihat adanya pertambahan diameter untuk masing-masing umur tanaman (Gambar 2). Pengaruh kompos terbaik terhadap respon pertambahan diameter ditunjukkan pada perlakuan K2 (7.5 kg tanaman $\left.{ }^{-1}\right)$ mampu meningkatkan diameter tanaman umur 1 tahun dimana adanya peningkatan 0.18 $\mathrm{cm}$ menjadi $0.46 \mathrm{~cm}$ dan pada umur 3 tahun menunjukkan terjadinya peningkatan dari $0.16 \mathrm{~cm}$ menjadi $0.74 \mathrm{~cm}$. Sedangkan pada umur 2 tahun juga mengalami peningkatan dari $0.27 \mathrm{~cm}$ menjadi $0.90 \mathrm{~cm}$ dengan pengaruh kompos terbaik pada perlakuan K3 $\left(10 \mathrm{~kg} \operatorname{tanaman}^{-1}\right)$. Hal ini disebabkan meningkatanya unsur hara $\mathrm{P}$ di tanah sehingga mendukung pertumbahan diameter tanaman. Marschner (1986) fungsi $\mathrm{P}$ penting untuk pertumbuhan dan metabolisme tanaman, karena kekahatan $\mathrm{P}$ dapat menghambat sebagian besar proses-proses pengembangan dan pembelahan sel.

\section{SIMPULAN}

Aplikasi kompos tandan kosong kelapa sawit (TKKS) mempengaruhi kesuburan tanah pada semua umur tanaman dimana mampu meningkatkan unsur hara C-organik, pH, KTK, P-total, N-total sehingga efektif meningkatkan pertumbuhan tanaman kayu putih (Melaleuca cajuputi). Secara umum perlakuan aplikasi kompos TKKS dengan perlakuan K1 (5 kg tanaman $\left.{ }^{-1}\right)$ merupakan dosis terbaik untuk umur tanaman 1 dan 2 tahun. Selain itu perlakuan K2 (7.5 kg tanaman $\left.{ }^{-1}\right)$ memberika respon terbaik pada umur tanaman 3 tahun. Penambahan TKKS secara signifikan meningkatkan pertumbuhan tinggi dan diameter tanaman.

\section{UCAPAN TERIMAKASIH}

Penulis mengucapkan terimakasih kepada Global Innovation Initiatif untuk menjadi bagian dari kerjasama penelitian dan PT. Bukit Asam sehingga penelitian ini dapat diselesaikan dengan baik.

\section{DAFTAR PUSTAKA}

[Balit Tanah] Balai Penelitian Tanah. 2009. Analisis Kimia Tanah, Tanaman, Air, dan Pupuk. Bogor (ID): Balai Penelitian Tanah

Budiadi HT, Ishii HT, S Sunarto, Y Kanazawa Y. 2005. Variation in Kayu Putih (Melaleuca leucadendron Linn) Oil Quality under Different Farming System in Java, Indonesia. Eurasian Journal Forestry Research, 8(1), 15-20

Bulan R. 2016. Pengembangan Sistem Mekanisasi Pemanfaatan Pelepah Kelapa Sawit Untuk Mulsa dan Kompos. [Disertasi]. Bogor (ID): Institut Pertanian Bogor.

Darnoko, Ady SS. 2006. Pabrik Kompos di Pabrik Sawit. Tabloid Sinar Tani, 9 Agustus 2006.

Darmawan J, Baharsjah JS.2010. Dasar-Dasar Fisiologi Tanaman. Jakarta (ID):SITC.

Gunn B, McDonald M, Lea D. 1996. Seed and leaf Colelections of Melalleuca cajuputil Powel in Indonesia and Northern Australia. Canberra (AUS): Australian Tree Seed Centre, CSIRO Forest and Forest Product. 
Hardjowigeno S. 2007. Ilmu Tanah. Edisi Baru. Cetakan Keenam. Jakarta: Akademika Pressindo.

Hakim N, Nyakpa MY, Lubis AM, Nugroho SG, Diha MA, Hong GB, Bailey HH. 1986. Diktat DasarDasar Ilmu Tanah. Lampung: Universitas Lampung.

Kurniaty R, Bustomi S, Widyati E. 2013. Penggunaan Rhizobium dan Mikoriza dalam Pertumbuhan Bibit Kaliandra (Calliandra callothyrsus) Umur 5 Bulan. Jurnal Perbenihan Tanaman Hutan. 1(2) : $71-81$.

Lewenussa A. 2009. Pengaruh mikoriza dan bio Organik terhadap pertumbuhan bibit Cananga odorata (Lamk) Hook.fet \& Thoms [Skripsi]. Bogor (ID): Institut Pertanian Bogor.

Mansur I. 2008. Pemilihan jenis tanaman kehutanan untuk rehabilitasi lahan bekas tambang. Makalah disampaikan dalam Seminar air asam tambang di Indonesia ke 3 dan Seminar reklamasi lahan bekas tambang di Indonesia, Bandung, 1-2 Juli 2008. Bandung: Institut Teknologi Bandung bekerjasama dengan Departemen ESDM dan Kementrian Lingkungan Hidup RI.

Mansur I. 2013. Teknik silvikultur untuk reklamasi lahan bekas tambang. Bogor (ID): SEAMEO BIOTROP Pr.

Marschner H. 1986. Mineral Nutrition of Higher Plant. London: Academic Press.

Munawar A. 2011. Kesuburan Tanah dan Nutrisi Tanaman. Bogor (ID) IPB Press.

Perum Perhutani. 2005. Rencana pengaturan kelestarian hutan kelas perusahaan kayu putih dari KPH Madiun bagian hutan: Sukun BKPH. Madiun (ID): Perum perhutani unit II Jawa Timur.
Prasetyo BH, Suriadikarta DA. 2006. Karakteristik, Potensi, dan Teknologi Pengelolaan Tanah Ultisol untuk Pengembangan Pertanian Lahan Kering di Indonesia. Jurnal Litbang Pertanian. 25(2) : $39-$ 46.

Purwowidodo. 1991. Gatra Tanah dalam Pembangunan Hutan Tanaman. Bogor (ID): IPB Press.

Sarwono E. 2008. Pemanfaatn Jajang Kosong Kelapa Sebagai Substitusi Pupuk Tanaman Kelapa Sawit. Jurnal Aplika. Vol 8 (1):19-23.

Sitompul SM, Guritno B.1995. Analisis Pertumbuhan Tanaman. Yogyakarta (ID): Gajah Mada University Press.

Siregar UJ, Sidabutar J, Siregar CA.2013. Perubahan Karakteristik Kimia Tanah pada Model Reklamasi Lahan Bekas Tambang PT. Antam UBPE Pongkor. Jurnal Silvikultur Tropika. 4 (3) :141 149.

Stevenson FJ. 1982. Humus Chemistry: Genesis, Composition, Reaction. New York (US): John Willey.

Talaohu SH, Irawan. 2008. Reklamasi lahan pasca penambangan batubara. Konservasi tanah Menghadapi Perubahan Iklim (8): 187-211.

[USDA] United States Departement of Agriculture. 1987. Soil Mechanics Level I- module 3 USDA Textural Soil Classification. Washington (US): Unites States Departemen of Agriculture.

Utomo PM. 2012. Model Produksi Daun Pada Hutan Tanaman Kayu Putih. Disertasi. Bogor (ID): Institut Pertanian Bogor.

Winarti S, Neneng L. 2013. Pengaruh pemberian limbah kelapa sawit terhadap sifat fisik, kimia dan biologi tanah pada lahan kritis eks penambangan emas. $J$ Agripeat. 14(2): 53-58. 